\title{
Ethno-Artistic Competence of Student Youth: Diagnostic Procedure
}

\author{
Qiao Zhi \\ ORCID https://orcid.org/0000-0002-0532-3111 \\ Postgraduate student (China) \\ Dragomanov National Pedagogical University (Ukraine, Kyiv)
}

\begin{abstract}
The article deals with the author's definition of personality's ethno-artistic competence as an integral personal formation in the context of ethnic intercultural dialogue. Ethno-artistic competence is considered as a result of students' immersing into a variety of folklore - music, poetry, dance, theater, arts and crafts, which is acquired during musical training. The author considers the ethnoartistic competence to be an integral part of person that unites the aspects of ethnic preparation based on native folklore and polyethnic aspects. Polyethnicity predicts the result of interethnic artistic and creative tolerance and respect for human attitudes toward folklore of other ethnic cultures. The author presents the results of an empirical study on the diagnostics of ethno-artistic competence of students. The information obtained serves as the guidelines to improve ethno-artistic training of students.

The structure of ethno-artistic competence has been distinguished; the content of the components (ethnocognitive, motivational-activity, reflexive, communicative and poly-ethnic) has been considered; the criteria for its diagnostics (emotional-value, ethno-cognitive, motivational-activity, reflexive, communicative and polyethnic) have been substantiated; the characteristics of the studied quality have been specified. The interrelation between content of the components during diagnostics is taken into account.
\end{abstract}

Key words: ethno-artistic competence, students, diagnosis, criteria and indicators.

Актуальність проблеми. Нині світ спостерігає за тим, як у глобалізаційних процесах посилюються тенденції зближення культур і водночас прагнення етносів збереження ідентичності. Стосовно мистецької освіти ці проблеми відображено в документах ЮНЕСКО (Конвенція ЮНЕСКО «Про охорону та заохочення розмаїття форм культурного самовираження»), а також в законодавстві різних країн, зокрема Китаю (Державна національна програма «Китай - XXI століття», Стратегія розвитку освіти в Китаї в XX1 ст. та ін.), України (Національна стратегія розвитку освіти в Україні на період до 2021 року, документи «Нової української школи», Концепція художньо-естетичного виховання учнів у загальноосвітніх навчальних закладах України).

Питання етнокультурного розвитку як важливі для міжкультурного 
діалогу, співіснування в мультикультурному світі, привертають увагу в теоретичному $\mathrm{i}$ прикладному напрямі (Вей Лімін, В. Дикало, Інь Хань, М. Качур, І. Кон, С. Лур’є, Ю. Руденко, Л. Петько, Сунь Гоцян, Сююй Цзяюй, Хай Лінь, О. Хижна, І. Ціко, Лібінь, Чень Ін, Г. Яківчук). Суттєвими для розуміння етнопсихологічні й фольклористичні праці (Ю. Бромлей, А. Іваницький, ЛуЛу, С. Лурье). «Мистецтво у складні для будь якого етносу часи стає силою, що спонукає людину визначатися в етнічному плані» [16, c. 16]. Загострення в юнацькому віці проблеми міжособистісного діалогу, вагомим чинником здатності до якого є фольклор різних національних культур і видів мистецтва, актуалізує методичні аспекти формування етномистецької компетентності.

Мета статті - визначити критерії та показники, за якими доцільно ідентифікувати сформованість етномистецької компетентності молоді.

Виклад основного матеріалу. Спираючись на аналіз джерел [1; 6; 9; 17], етномистецьку компетентність тлумачимо як інтегральний особистісний феномен, що характеризує освоєння людиною мистецьких традицій власного етносу, виявляється в мотивації до етномистецького пізнання у комплексі знань, умінь опанування традицій; в дієво-ціннісному ставленні до фольклору рідного етносу (емоційністю переживання, рефлексії та самооцінки); презентується у спроможності відтворення й примноження в комунікації з представниками свого етносу, в пошануванні і толерантності інших етнокультур [14; 15]. Отже, цілісну структуру етномистецької компетентності складають етнокогнітивний (конкретизуєтся у площині різновидів мистецького фольклору), аксіологічний, діяльнісно-творчий, мотиваційний, рефлексивний, комунікативний, та власне естетичний компоненти (умовно, його зміст пронизує решту компонентів) [14].

Критеріями є: емоційно-ціннісний (відповідає одночасно аксіологічному та естетичному компонентам); етнокогнітивний; мотиваційно-діяльнісний; рефлексивний; комунікативно-поліетнічний. Зміст кожного з критеріїв може виявляти себе через спільні характеристики і показники.

Емоційно-иіннісний критерій зосереджений на особливостях емоційно-ціннісного ставлення до народного мистецтва рідного краю, що виявляється в та мірі інтересу до мистецького явища, навичках сприймання творів у єдності емоційності сприймання та аналізу-інтерпретації творів, коли відбувається осмислення сприйнятого; на з'ясуванні 
того, чи увійшло сприйняте до особистісних цінностей (бажанні опановувати нові для себе художні цінності, популяризувати їх). Цей критерій є мірилом емоційної сфери поряд зі здатністю рефлексії: ціннісне ставлення неможливе поза переживанням сприйнятих творів і здатністю виокремлювати естетичний смисл творів та зіставити його з реаліями: відбувається ідентифікація особистості з культурою етносу, а також відбувається вирізнення свого від «іншого» [2; 3]. Етнічна мистецька традиція реалізує свій педагогічний потенціал, коли створює у свідомості особистості глибокий емоційний образ етносу, формуючи у людини ціннісну позицію щодо себе $[4 ; 5 ; 17 ; 20 ;$ $21 ; 22]$.

Етнокогнітивний критерій зосереджений на діагностуванні знань вітчизняного фольклоруу єдності драматургічного, музичного, танцювального, декоративноприкладного, поетичного, атрибутивного складників, пам’яток культури, уявлень спадщину відомих митців, зокрема тих, чия творчість спирається на народні традиції; а також враховує аналогічну обізнаність у народному мистецтві інших етносів. Оцінювання сформованості етномистецької компетентності за етнокогнітивним критерієм розвиває художню ерудованість, визначає, якому мистецтву особистість надає перевагу та наскільки i щодо яких мистецтв учень володіє мистецьким тезаурусом, наскільки уміє проводити паралелі між художніми образами та життям.

Усвідомлення пізнаного стимулює подальше поглиблення знань; формується рефлексія як здатність свідомого ставлення до фольклору рідного та інших етносів.

Мотиваційно-діяльнісний критерій виявляє готовність до практичного освоєння та поширення рідного фольклорного матеріалу та інших культур. Фіксується художньопрактичний досвід ознайомлення 3 фольклорними цінностями, виконавські уміння, вмотивованість до пізнання, інтерпретації, вивчення й виконання творів, поширення й уведення пізнаного у власне дозвілля. Усі ці прояви неможливі поза дією емоційної сфери і ціннісними орієнтаціями, а також поза уміннями аналізу та навичками виконавської діяльності та прагненнями творчого самовираження в ній. Оцінюючи сформованість етномистецької компетентності учнів за цим критерієм, передбачаємо: саме в діяльності виявляються характеристики, які відображені в етнокогнітивному й емоційно-ціннісному критеріях, а в саму діяльність учні включаються за умови розвиненості мотивації. 
Рефлексивний критерій охоплює як осмислення художньої значущості творів, що пізнаються у сприйманні та в практичній діяльності, так і усвідомлення власної причетності до рідного етносу й невід’ємності від національної мистецької спадщини, усвідомлення місця мистецтва в цілому або певних його видів та жанрів у своєму житті. Важливим в оцінюванні етномистецької компетентності є усвідомлення можливостей мистецтва відображати внутрішній світ іншої людини і цілого етносу та усвідомлювати себе у зв'язках з іншими на основі сприймання конкретних творів. Розвиток рефлексії як усвідомлення і «творіння» самого себе, пов’язаний з діалогічним процесом переживання художніх образів у процесі сприймання та інтерпретації, осмислення своїх вражень тощо [11; 13; 18; 19;]. Під діалогом слід розуміти, на наш погляд, діалог з образністю творів рідного мистецтва i 3 образністю, жанровими, мовними особливостями мистецьких явищ інших етнічних культур. Отже, оцінювання етномистецької компетентності за рефлексивним критерієм також пов'язано зі змістом решти критеріїв.

Комунікативно-поліетнічний критерій враховує, наскільки усвідомлюється значення мистецтва як засобу комунікації людей і культур; охоплює, толерантність ставлення до народного мистецтва інших етносів, що акумулює емоційність їх сприймання й розуміння цінності у світовій культурі, обізнаність 3 іншоетнічною традиційною культурою й мистецькими явищами, вмотивованість до пізнання, інтерпретації, практичного освоєння, осмислення «інакшості» своєї культури у порівнянні 3 іншими i навпаки. Застосування цього критерію передбачає, що поліетнічність постає у двох вимірах: як толерантність ставлення і спілкування 3 мистецтвом етносів у межах рідної культури з усвідомленням ролі в цілісності культури та ii взаємозбагаченні, а також толерантність ставлення і спілкування 3 мистецтвом інших етнічних культур Світу.

Відповідно до змісту критеріїв до кожного з них визначаємо показники.

Показниками емоційно-цуіннісного критерію є:емоційність сприймання і виконання творів рідного мистецтва та інших етнічних культур;здатність інтонаційної ідентифікації мистецького матеріалу різної етнічної належності на елементарночуттєвому рівні (серед вивчених творів);інтерес до рідного фольклору та прихильне ціннісно-смислове ставлення до іншоетнічного фольклору різних видів і жанрів. 
Показниками етнокогнітивного критерію є: знання рідних мистецьких традицій; обізнаність у мистецьких етнічних традиціях інших культур; уміння здійснювати аналіз-інтерпретацію творів.

Показниками мотиваційно-діяльнісного критерію є: потреба практично-творчого опанування мистецьких творів рідної культури в навчально-виховній діяльності та у дозвіллі (ознайомлення, сприймання, вивчення, виконання, поширення); прагнення самовираження і самовдосконалення через практичну діяльність у процесі пізнання рідного фольклору; вмотивованість до ознайомлення з фольклором інших культур 3 прихильним ставленням до них.

Показниками рефлексивного критерію є: усвідомлення причетності до рідної культури через освоєні мистецькі явища;усвідомлення відмінності і спільності мистецьких традицій рідної та інших етнічних культур;прагнення осмислювати власну творчість.

Показниками комунікативно-поліетнічного критерію $\epsilon$ : готовність до ознайомлення 3 мистецтвом інших етнічних культур та толерантне ставлення до іншоетнічних відмінностей у мистецькому фольклорі; прагнення зіставляти мистецькі твори рідної культури та інших етнічних культур (сюжети, жанри, засоби виразності); знання правил толерантного спілкування й уміння застосовувати їх у спільному пізнанні мистецтва.

Висновки. Застосування запропонованого діагностувального інструментарію дозволить вчасно виявляти проблеми і недоліки у процесі пізнання мистецтва рідного етносу та інших етносів, які складають єдину культурну картину світу, окреслить перспективні методики такого пізнання..

\section{References}

1. Dykalo V.I. Muzychn ekraieznavstvo Rivnenshchyny yak navchalnyikurs: do postanovky problem [Music regional studies of Rivne as a training course: before the problem]. Nova pedahohichna dumka. 2016. No 32 (86). P. 124-128.

2. Komarovska O.A. Mystetski dosiahnennia uchniv: shcho i yak otsiniuiemo? [The pupils' artistic achievements: What do we appreciate?].Mystetstvo ta osvita. 2018. No 4. P.2-7

3. Komarovska O.A. Artistic-intonational space of life as a source of values of personality's developing: psychological and pedagogical aspects. Topical issues of education: Collective monograph. Pegasus Publishing, Lisbon, Portugal, 2018. P. 260-280. 
4. Komarovska O. A. Khudozhnii obraz tvoru yak proiav obdarovanosti myttsia [Artistic image of a work as display of gifted artist]. Mystetstvo ta osvita. 2009. No 4. P. 4-6.

5. Komarovska O. A. Shkola estetychnoho vykhovannia u systemi mystetskoi osvity [School of aesthetic education in the system of artistic education]. Psykholoho-pedahohichni problemy silskoi shkoly: zb. nauk. prats Umanskoho derzh. ped. un-tu im. Pavla Tychyny. Uman: PP Zhovtyi O. O., 2012. Issue 40. P. 312-319.

6. Kontseptsiia khudozhno-estetychnoho vykhovannia uchniv $u$ zahalnoosvitnikh navchalnykh zakladakh ta Kompleksna prohrama khudozhno-estetychnoho vykhovannia $u$ zahalnoosvitnikh ta pozashkilnykh navchalnykh zakladakh [Concept of artistic and aesthetic education of students in general educational institutions and Integrated program of artistic and aesthetic education in general and out-of-school educational institutions]. MON Ukrainy. Nakaz No 151/11 vid 25.02.2004. URL: http://zakon.rada.gov.ua/rada/show/ru/v1_11290-04.

7. Mystetstvo. Navchalna prohrama dlia zahalnoosvitnikh navchalnykh zakladiv. 5-9 klasy [Art.Educational program for general educational institutions. 5-9 grades.]. URL: https://ru.osvita.ua/school/program/program-5-9/56132/

\section{Mystetstvo. Prohrama dlia zahalnoosvitnik hnavchalnykh zakladiv 10-11 klasy [Art. Program for general education institutions 10-11 grades]. URL: https://mon.gov.ua/ua/osvita/zagalna-serednya-osvita/navchalni-programi/navchalni-programi- dlya-10-11-klasiv}

9. Osypets R. O. Formuvannia natsionalnoi samosvidomosti maibutnikh uchyteliv zasobamy ukrainskoi narodnopisennoi kultury [Formation of national self-consciousness of future teachers by means of Ukrainian folk song culture]. Kyiv: Mahister-S, 1999. 207 p.

10. Pankiv L. I. Formuvannia mystetskykh oriientatsii starshoklasnyka yak vektor dukhovnoho rozvytku osobystosti [Formation of artistic orientations of a senior pupil as a vector of spiritual development of personality]. Mystetstvo ta osvita. 2016. No 1. P. 16-19.

11. Pet'ko L.V. Shljahy formuvannja inshomovnoi' sociokul'turnoi' kompetencii' studentiv mystec'kyh special'nostej VNZ u procesi fahovoi' pidgotovky [The Ways of Formation of Foreign Language Socio-Cultural Competence of Students of Music-Pedagogical Specialties in Higher School in the Process of Professional Teaching]/ Problemy pidgotovky suchasnogo vchytelja: $\mathrm{zb}$. nauk. pr. Umans'kogo derzhavnogo ped. un-tu imeni Pavla Tychyny. Uman: PP Zhovtyj O.O., 2012. Vol. 6. Part 3. P. 57-62.

12. Pet'ko L.V., Danilko E.V. Vzaimodejstvie iskusstv na urokah muzyki v srednej obshheobrazovatel'noj shkole [Cooperation of arts on the Music lessons in secondary school]: Tez. dokl. uchastnikov mezhrespublikanskogo seminara-soveshhanija. Voroshilovgrad. 1990. P. 43-47.

13. Rudnytska O. P. Muzyka i kultura osobystosti: problem suchasnoi pedahohichnoi osvity [Music and culture of personality: problems of modern pedagogical education]. Kyiv, 1998. $248 \mathrm{p}$.

14. Qiao Zhi. Sutnist etnokulturnoi kompetentnosti: teoretychnyi aspect [The essence of ethno-cultural competence: Theoretical aspect]. Teoretyko-metodychni problem vykhovannia ditei ta uchnivskoi molodi. Vol. 20, Issue. 2. Kyiv, 2016. P. 297-306. 
15. Qiao Zhi, Komarovska O. A. Kytaiski narodni tradytsii v muzychnomu navchanni ukrainskykh shkoliariv [Chinese folk traditions in musical education of Ukrainian schoolchildren]. Mystetstvo ta osvita. 2017. No 4. P. 6-10.

16. Shulha R. P. Mistse etnichnoho faktoru $v$ protsesi funktsionuvannia mystetstva [Place of ethnic factor in the process of functioning of art]. Teoretychni problemy khudozhnoi kultury: zb. nauk. st. Pereiaslav-Khmelnytskyi, 1995. Issue. 1. P. 14-18

17. Yakivchuk H. V. Vykhovannia tvorchoi osobystosti maibutnoho vchytelia muzyky u protsesi vyvchennia ukrainsko homuzychnoho folklore [Education of creative personality of future music teacher in the process of studying Ukrainian folk music]. Avtoreferat of dissertation. Kyiv, 2009. 20 p.

18. Komarovska Oksana, Huang Hanjie. Readiness for stage partnership in vocal-ensemble performance as a vector in professional training music teacher. Intellectual Archive. - Toronto: Shiny Word.Corp. (Canada). 2018. (September/October). Vol. 7. No. 5. PP. 66-74. (https://doi.org/10.32370/2018_09_7)

19. Pet'ko Lyudmila. About socio-culturological content in teaching subjects / Lyudmila Pet'ko // Development strategy of science and education: Collection of scientific articles. - Fidelite editions, Namur, Belgique, 2017. - P. 316-319.

URI http://enpuir.npu.edu.ua/handle/123456789/13881

20. Pet'ko L.V. Formation of professionally oriented foreign language teaching environment in the conditions of university for students of specialties 023 «Fine Arts» and 022 «Design». Economics, management, law: realities and perspectives: Collection of scientific articles. Psychology. Pedagogy and Education. - Les Editions L'Originale, Paris, France. 2016. P. 466-470.

21. Pet'ko Lyudmila. Sociocultural comprehension of ethnoconcept "RED RUE" // Science and society: Collection of scientific articles. - Edizioni Magi, Roma, Italia, 2017. P. 460-466. URI http://enpuir.npu.edu.ua/handle/123456789/18483

22. Shcholokova O.P. Art and pedagogical designing as a means of improvement ofmusic teacher's professional preparing. Economics, management, law: socio-economical aspects of development: Collection of scientific articles. Volum 2. Edizioni Magi, Roma, Italy. 2016. P. 265-268.

\section{Translation of the Title, Abstract and References to the Author's Language}

УДК [37.01: 373-379.8] : 398

Цяо Чжи. Етномистецька компетентність учнівської молоді: процедура діагностування.

У статті подано авторське тлумачення етнокультурної компетентності особистості як інтегрального особистісного утворення в контексті полі етнічного міжкультурного діалогу. Етномистецька компетентність подається як результат занурення учнів у різновиди фольклору - музичного, поетичного, танцювального, театрального, декоративно-прикладного мистецтва, який опановується під час музичного навчання. Виокремлено структуру етномистецької компетентності, розглянуто зміст компонентів та обгрунтовано критерії її діагностування (емоційно- 
ціннісний, етнокогнітивний, мотиваційно-діяльнісний, рефлексивний, комунікативнополіетнічний); конкретизовано показникові характеристики досліджуваної якості.

Ключові слова: етномистецька компетентність, учнівська молодь, діагностування, критерії та показники.

\section{Лimepamypa}

1. Дикало В. I. Музичне краєзнавство Рівненщини як навчальний курс: до постановки проблеми. Нова педагогічна думка. 2016. 32 (86). С. 124-128.

2. Комаровська О.А. Мистецькі досягнення учнів: що і як оцінюємо?. Мистейтво та освіта. 2018. № 4. С. 2-7.

3. Комаровська О. А. Художньо-інтонаційний простір життя як джерело цінностей підростаючої особистості. Topical issues of education: Collective monograph. Pegasus Publishing, Lisbon, Portugal, 2018. P. 260-280.

4. Комаровська О.А. Художній образ твору як прояв обдарованості митця. Мистейтво та освіта. 2009. № 4. С. 4-6.

5. Комаровська О. А. Школа естетичного виховання у системі мистецької освіти. Психолого- педагогічні проблеми сільської школи : зб. наук. праць Уманського держ. пед. ун-ту ім. Павла Тичини / [ред. кол.: Побірченко Н. С. (гол. ред.) та ін.]. - Умань : ПП Жовтий О. О., 2012. Вип. 40. С. 312-319.

6. Концепція художньо-естетичного виховання учнів у загальноосвітніх навчальних закладах та Комплексна програма художньо-естетичного виховання у загальноосвітніх та позашкільних навчальних закладах / Наказ МОН України від 25.02.2004. № 151/11 URL: http://zakon.rada.gov.ua/rada/show/ru/v1_11290-04.

7. Мистецтво. Навчальна програма для загальноосвітніх навчальних закладів. 5-9 класи. URL: https://ru.osvita.ua/school/program/program-5-9/56132/

8. Мистецтво. Програма для загальноосвітніх навчальних закладів 10-11 класи. URL: https://mon.gov.ua/ua/osvita/zagalna-serednya-osvita/navchalni-programi/navchalniprogrami-dlya-10-11-klasiv

9. Осипець Р. О. Формування національної самосвідомості майбутніх учителів засобами української народнопісенної культури. Київ: Магістер-S, 1999. 207 с.

10. Паньків Л. І. Формування мистецьких орієнтацій старшокласника як вектор духовного розвитку особистості. Мистецтво та освіта : науково-методичний журнал. 2016. № 1 . С. 16-19.

11. Петько Л. В. Шляхи формування іншомовної соціокультурної компетенції студентів мистецьких спеціальностей ВНЗ у процесі фахової підготовки // Проблеми підготовки сучасного вчителя: зб. наук. пр. Уманського державного пед. ун-ту імені Павла Тичини / [ред. кол.: Побірченко Н.С. (гол.ред) та ін.]. - Умань: ПП Жовтий О.О., 2012. Вип. 6. Ч. 3. С. 57-62.

12. Петько Л. В., Данилко Е. В. Взаимодействие искусств на уроках музыки в средней общеобразовательной школе // Взаимодействие искусств в духовном развитии школьников: Тр. докл. участников межреспубликанского семинара-совещания 17-19 
апреля 1990 г. Ворошиловград: Редакционно-издательский отдел облполиграфиздата. 1990. C. 43-47.

13. Рудницька О. П. Музика і культура особистості: проблеми сучасної педагогічної освіти. Київ, 1998. 248 с.

14. Цяо Чжи. Сутність етнокультурної компетентності: теоретичний аспект // Теоретико-методичні проблеми виховання дітей та учнівської молоді: зб. наук. пр. Київ, 2016. Вип. 20. Кн. 2. С. 297-306.

15. Цяо Чжи, Комаровська О.А. Китайські народні традиції в музичному навчанні українських школярів. Мистецтвво та освіта. 2017. № 4. С. 6-10.

16. Шульга Р. П. Місце етнічного фактору в процесі функціонування мистецтва // Теоретичні проблеми художньої культури: зб. наук. ст. Переяслав-Хмельницький, 1995. Вип. 1. С. 14-18.

17. Яківчук Г. В. Виховання творчої особистості майбутнього вчителя музики у процесі вивчення українського музичного фольклору : автореф. дис. ... канд. пед. наук: 13.00.07. Київ, 2009. 20 с.

18. Komarovska Oksana, Huang Hanjie. Readiness for stage partnership in vocal-ensemble performance as a vector in professional training music teacher. Intellectual Archive. - Toronto: Shiny Word.Corp. (Canada). 2018. (September/October). Vol. 7. No. 5. PP. 66-74. (https://doi.org/10.32370/2018_09_7)

19. Pet'ko Lyudmila. About socio-culturological content in teaching subjects. Development strategy of science and education: Collection of scientific articles. - Fidelite editions, Namur, Belgique, 2017. - P.316-319. URI

http://enpuir.npu.edu.ua/handle/123456789/13881

20. Pet'ko L V. Formation of professionally oriented foreign language teaching environment in the conditions of university for students of specialties 023 «Fine Arts» and 022 «Design». Economics, management, law: realities and perspectives: Collection of scientific articles. Psychology. Pedagogy and Education. - Les Editions L'Originale, Paris, France. 2016. P. 466-470.

21. Pet'ko Lyudmila. Sociocultural comprehension of ethnoconcept "RED RUE" // Science and society: Collection of scientific articles. - Edizioni Magi, Roma, Italia, 2017. - P. 460-466. URI http://enpuir.npu.edu.ua/handle/123456789/18483

22. Shcholokova O.P. Art and pedagogical designing as a means of improvement ofmusic teacher's professional preparing / O.P. Shcholokova // Economics, management, law: socio-economical aspects of development: Collection of scientific articles. Volum 2. Edizioni Magi - Roma, Italy. - 2016. - P. 265-268. 